\title{
時空間分析による河川堤外地の社会生態学的生産ランドスケープ特性の考察 \\ Evaluation of socio-ecological production landscape of the riverside area by a spatio-temporal analysis
}

\author{
矢澤 優理子* 古谷 勝則* \\ Yuriko YAZAWA Katsunori FURUYA
}

\begin{abstract}
In this study, the amount of nature formed outside a river embankment due to people use, and the background around its formation is explained; additionally, the mosaic nature of that environment around the rivers in the Kanto region is also evaluated. Using a Geographic Information System to categorize the past and present vegetation type, this study examined the changes in the types of vegetation for each $100 \mathrm{~m}$ mesh. To evaluate the mosaic nature of the landscape, the riverside area was divided every one $\mathrm{km}$ according to the distance marker of each river, overseeing the extent of the nature formed by people use in that area. As a result, it was found that $45.1 \%$ of the natural environment formed due to people use existed outside the embankment in the target area. It is suggested that land-use in nature formed due to people use have changed because of the decrease of people's maintenance and flood. Furthermore, the nature formed by people use is mosaic represents $52.7 \%$ of the total region. This shows that the riverside area also has a Socio-Ecological Production Landscapes based on the nature formed by people use similar to Satoyama, which is associated with traditional human lifestyles.
\end{abstract}

Keywords: riverside area, nature formed due to people use, socio-ecological production landscapes and seascapes, satoyama, GIS

キーワード：堤外地，人為的自然環境，社会生態学的生産ランドスケープ，里地里山，GIS

\section{1. はじめに}

2010 年に開催された第 10 回生物多様性条約締約国会議 （COP10）において日本の里地里山が紹介され，それらの伝統的 集落が「社会生態学的生産ランドスケープ」（socio-ecological production landscapes and seascapes）として注目を集めるよう になった。社会生態学的生産ランドスケープは,「生物多様性を維 持しながら, 人間の福利に必要な物品・サービスを継続的に供給 するための人間と自然の相互作用によって時間の経過とともに形 成されてきた生息・生育地と土地利用の動的モザイク」1)と定義さ れ, 以降関連する研究やランドスケープ保全等が行われてきた。 例えば，伝統的な生活様式や集落構造を残す地域を「重要里地里 山」として選定する環境省の取組み 2,3)や, 世界的に重要かつ伝統 的な農林水産業を営む地域や農林水産業システムを「世界農業遺 産認定地域」として認定する制度の確立 ${ }^{4)}$ が政府や国際機関によ り行われてきた。また, 社会生態学的生産ランドスケープにおけ る生態系サービスの機能評価を行った Ciftcioglu の研究 5)や, 石川 県能登半島における生態系サービスのシナジーとトレードオフの 仕組みを解明した神山らの研究 6)，世界各国を対象とした社会生 態学的生産ランドスケープに対する行政と地域社会の認識と, 景 観保護過程の分析を行った $\mathrm{Gu}$ らの研究7)な゙が行われている。

これらの先行事例では, 狭小・急峻な地形をうまく利用して農業 生産を行ってきた中山間地域や，半農半漁の生産形態を維持する 漁村が主な対象地域として取り上げられてきたが，社会生態学的 生産ランドスケープの主要な一要素である河川はこれまであまり 着目されてこなかった。里地里山地域が注目されるようになる中 で, 人の生活に関わる地域の河川が「里川」として定義されてきた 事例もあるが 8), 洗濯や遊び場としての河川利用にとどまり, ラン ドスケープを構成寸る土地利用システムという側面から河川空間 をとらえた事例はなかった ${ }^{9)}$ 。

河川沿岸は水を得やすく肥沃な土潩が形成されているため, 古 くから人の生活基盤であった。特に，堤防間に挟まれた河川空間
である堤外地においては，出水により家屋や農作物への被害が起 きる状況下にあっても様々な土地利用がなされ，今日まで生産活 動が続けられてきた。例えば，関東地方の堤外地は，「原地，「秣 場」といった肥料供給の場として活用されてきたが，1700年代初 期に新田開発が進み，中洲や河岸付近に流作場という生産空間が 成立したと言われている 10)。また，これまでに流作場に関する大 石，松尾らの研究 11,12$) や ，$ 磯谷らによる荒川堤外地の集落移転に 関寸る研究 13$)$ ，矢澤らによる堤外地の入会地に関する研究 14)，千 曲川流域の伝統的な農地区分方法である地割慣行に関する吉田の 研究 15)など，堤外地における空間利用を詳細に解明した研究も行 われている。これらを踏まえると，堤外地にも里地里山地域と同 様に人の擋乱を受けて成立した「人為的自然環境」が形成され，社 会生態学的生産ランドスケープが成立してきたと考えられるが, 堤外地にどの程度の人為的自然環境が存在しているのかといった 量的実態やその形成過程は，これまで明らかにされてこなかった。

近年想定規模を超える豪雨による激甚水害が頻発し，水害防備 体制の確立が喫緊の課題となっている。一方で，エコトーンとし ての堤外地が陸水域の生態系を維持する上で重要であるという指 摘が様々な分野でなされており 16)，社会生態学的生産ランドスケ 一プの基盤となる人為的自然環境のあり方も含め，汇濫原全体に おいて河川と共生できる土地利用を追究していくことが必要であ る。そのためにも，堤外地における人為的自然環境の量的把握と その形成過程を時空間的にとらえ，今後の河川管理や土地利用管 理に知見を反映していく必要があると考える。

そこで本研究では，堤外地における人為的自然環境の量とその 形成過程を明らかにするとともに，里地里山地域の空間的特徴の 一つである土地利用のモザイク性が堤外地にどの程度出現してい るかを評価することで, 堤外地の社会生態学的生産ランドスケー プの特性を考察することを目的とした。

本研究により，これまで明らかにされてこなかった堤外地にお ける人為的自然環境の実態が解明されれば，今後の河川空間や汇

\footnotetext{
*千葉大学大学院園芸学研究科
} 
濫原における土地利用政策を考えるうえでの一つの基礎資料とす ることができる。また，すでに研究が進んでいる里地里山地域の 空間利用システムと堤外地のそれを比較することで，堤外地の維 持管理手法を確立していく際にも有用である。

人為的自然環境については, これまで様々な用語により定義さ れてきた。例えばTansley は，人間の影響を受けてはいるが自然 の再生力によって形成された群落を「半自然」と表現している ${ }^{17) 。}$ また, 環境省や農林水産省は, 人間活動の影響を受けて形成・維持 されている自然環境を「二次的自然」と定義している 18, 19)。大澤 は, 撹乱要因が人為によるものでなくても, 自然条件下では出現 しない群落型が特定の人為要因に反応して出現するものを「二次 植生」としている 20)。これらの定義を踏まえ本研究では, 農地, 二次草原, 二次林等の代償植生に加え, 植林や人工草地等の人為 的要因により形成された自然環境を指し「人為的自然環境」の用 語を用いることとする。

\section{2. 対象地域の概要と研究方法 \\ (1) 対象地域の概要}

本研究の対象地域は, 東京都, 神奈川県, 埼玉県, 千葉県の 4 都 県 (東京圏) の一級水系本川である利根川, 荒川, 多摩川, 鶴見川, 相模川の堤外地とする (図一-1)。選定理由としては, 1) 東京圈の 河川は, 江戸時代以降積極的に開発が進められたこと，2）堤内地 の都市化が進行する中で, 農業を基盤とする伝統的な空間利用形 態が残されてきたこと，3）支川や派川等の流入出河川と比較して， 一級水系本川には広大な堤外地が形成され, 今日までに土地利用 が進んできたこと，4）以上 3 点の理由から，人が空間利用をする 中で社会生態学的生産ランドスケープが形成されてきたと考えら れることの 4 点を根拠とした。

また, 堤外地とは堤防の法尻から対岸の堤防の法尻までの高水 敷と低水路を合わせた区域であるが，堤外地のうち土地利用が可 能となる範囲は河川が山地を抜け扇状地が形成される地点より下 流部であるため, 本研究ではこの範囲を対象とした（図一1, 表一 1)。堤外地の範囲は国土地理院の提供する地形分類図と空中写真 をGIS 上で重ね合わせ，扇頂部より下流域の堤防をトレースして 決定した。GIS ソフトはArcGIS10.5，ArcGIS Pro2.5を用いた。

\section{(2) 研究方法}

1）堤外地における人為的自然環境の量と形成過程の把握

堤外地における過去から現在にかけての人為的自然環境の量と 形成過程を把握するため, 以下の作業を行った。まず, 明治時代初 期に作成された「第一軍管区陸地測量部二万分の一迅速即図原図」

(以下, 迅速図) 21)に描画された堤外地の植生 (土地利用) を GIS 上でトレースし, 現存植生が形成される以前の植生状況を GIS デ 一タ化した。明治期の地図資料は，有限な資源を有効に活用しよ うとした近世のシステムの名残をとらえることができるため, 景 観構造と人間活動の関係を考察する上で有用であるとされている 22)。また, 上述したように関東地方の河川では江戸時代に土地利用 が進んだが，明治期以降に各地で河川改修が行われ，私的な利用 が制限されるようになった。そのため, 明治初期の地図を用いる ことで堤外地において最も土地利用が盛んであった時代の空間状 況を把握できる。なお, 荒川下流部は大規模な河川改修により従 来の河川と全く異なる場所に放水路が造成されたため, 放水路完 成以降に最も土地利用が進んだ 1945 年前後 23)の地形図と空中写 真 24)を用いて同様の作業を行った。現在の植生については，環境 省生物多様性センターの提供する 2 万 5 千分の 1 現存植生図（第 6 回・第 7 回自然環境保全基礎調査により作成）を利用した。

次に, 各河川の堤外地を $100 \mathrm{~m}$ 四方のメッシュに区切り, 各メ ッシュに占める植生のうち最大面積の地目を代表させてメッシュ ごとの過去と現在の植生を決定した。この際, 堤防や堤内地の植

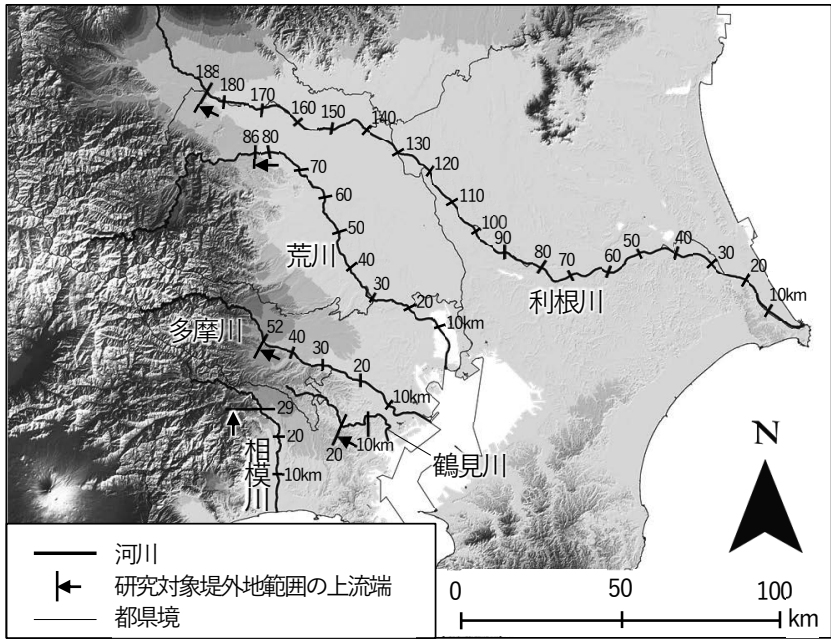

図-1 対象地域

表-1 研究対象範囲の概況

\begin{tabular}{|c|c|c|c|}
\hline 河川名 & 研究対象範进 & 主要地点川幅 ${ }^{*}$ & 平均河床勾配 ${ }^{*}$ \\
\hline 利根 & 河口～紷 & 約 $550-1000 \mathrm{~m}$ & 約 11 \\
\hline 荒 & 河口～約 86 km地点 & $0 \mathrm{~m}$ & 0,000 \\
\hline 多 & 河口〜約 & &, 500 \\
\hline 鶴見川 & 河口～約 $20 \mathrm{~km}$ 地点 & 約9 & 約 1/250-1/1,000 \\
\hline 相模川 & 河口～約 & 約 4 & 約1/500-1/2,700 \\
\hline
\end{tabular}

生をメッシュに含むことがないよう，メッシュ化された堤外地の 範囲を堤防線で切り取り, 堤外地のみの植生を評価できるように した。また，流路部分の水域はあらかじめ面積から除いた。

その上で, 堤外地における人為的自然環境の抽出を行った。環境 省による里地里山地域の評価 ${ }^{25)}$ では, 現存植生図の植生自然度 ${ }^{26}$ が $2 \cdot 3$ の農耕地と $4 \cdot 5$ の二次草原, $7 \cdot 8$ の二次林を里地里山環 境としている。また，河川本来の植生と代償植生を 6 段階に区分 し, 河川植生に特化した植生区分である「河川の自然性区分」が山 根らにより開発されている 27, 28)。本研究では, これらを踏まえ, 現在の植生において植生自然度が $2 \cdot 3$ の農耕地と $4 \cdot 5$ の二次草 原， $7 \cdot 8$ の二次林，河川の自然性区分において $1,2,3$ の代償植 生および人為植生を人為的自然環境とした。過去の植生について は，どこまで人為的圧力を受けたものなのかを厳密に判断するこ とが難しい。しかし, 迅速図の製図方法を記載した『兵要測量軌典』 29) とその補完資料『偵察録』30)を用いて迅速図上の植生記号の解明

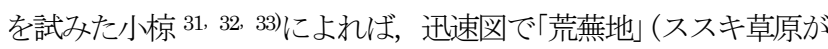
多い),「牧場或草地」,「撲叢」(柴草地) とされている山が『偵察録』 や同時代の他資料において「近村ノ秣場」や「草地撲叢山八早春 年々焼悉(やきつく)シ肥死トナシ…」「秝場」，「秝野」等として利 用されている記載があること，当時関東地方に多かったマツやク ヌギ，ナラ等の森林や落葉が建築用材や薪炭，燃料として活用さ れていたこと，また，水辺植生は河川の汇濫を受けるため陸域植 生とは異なる環境にあるものの, 水辺の草を秝とする例や「臀 (女 し）刚取等ノ入會」があったことなどから，水辺の低地植生にも人 為的影響が及ぶものがあると述べられている。上記既往研究や資 料の記述を踏まえ, 表-2 に示す過去の植生のうち， x . 建築物之 $\mathrm{xi}$ 及びxiïの自然地目を除く凡例を人為的自然環境に分類した。

以上を踏まえ, 各メッシュの過去と現在の植生を「植生タイプ」 として類型化した（表一2）。過去の植生は，『兵要測量軌典』に示 された迅速図の製図方法と既往研究 $31,32,33$ により示された土地利 用区分を諸元とし，地図上に記載された植生を現代の植生に整合 させて分類した ${ }^{34)}$ 。現存植生は，河川水辺の国勢調査における植 物群落の分類を基淮にした ${ }^{34)}$ 。これらの作業をすべてのメッシュ で行い, 各メッシュの過去から現在にかけての植生タイプの変化 を明らかにし，人為的自然環境の形成過程を把握した。 
表一2 対象地域における植生の分類と過去と現在の植生タイプ

\begin{tabular}{|c|c|c|c|c|c|c|}
\hline \multirow[b]{2}{*}{$\begin{array}{c}\text { 過去の植生分類 } \\
\text { (迅速図上の凡例) }\end{array}$} & \multicolumn{5}{|c|}{ 現在の植生分類 } & \multirow[b]{2}{*}{ 植生タイプ } \\
\hline & 植生分類 & $\begin{array}{c}\text { 環境省 } \\
\text { 植生自然度 } \\
\end{array}$ & $\begin{array}{l}\text { 河川の } \\
\text { 自然性区分 }\end{array}$ & $\begin{array}{c}\text { 河川水辺の国勢調査における } \\
\text { 植物群落の基本番号と分類 }\end{array}$ & $\begin{array}{c}\text { 人為的 } \\
\text { 自然環境 }\end{array}$ & \\
\hline 1. 湿地 & 塩沼地植生 & 10 & 5 & 03 塩沼植物群落 & & \multirow{12}{*}{ 草本主体型 } \\
\hline \multirow{11}{*}{$\begin{array}{l}\text { 2. 蘆, 芦, 陆, 葦, } \\
\text { 茅, 萱, 苽, 草 }\end{array}$} & 河辺一年生草本群落(タウコギクラス等) & 5 & 4 & 05一年生草本群落 & & \\
\hline & 路傍・空地雑草群落 & 4 & 2 & \multirow{2}{*}{06 多年生広葉草本群落 } & \multirow[b]{2}{*}{ 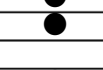 } & \\
\hline & カワラハハコ-ヨモキ群団 & 10 & 5 & & & \\
\hline & ミゾソバ-ヨシ群落 & 5 & 5 & \multirow{2}{*}{07 単子葉草本群落 } & & \\
\hline & ヨシクラス & 10 & 5 & & & \\
\hline & ツルヨシ群集 & 10 & 5 & \multirow{2}{*}{08 単子葉草本群落 } & & \\
\hline & オキ群集 & 10 & 5 & & & \\
\hline & 河川砂碟地外来草本群落 & 2 & 2 & \multirow{4}{*}{10 単子葉草本群落 } & & \\
\hline & チガヤーススキ群落 & 5 & 3 & & & \\
\hline & アズマネザサ-ススキ群集 & 5 & 3 & & & \\
\hline & ススキ群団(VII) & 5 & 3 & & & \\
\hline \multirow{2}{*}{ - } & 放棄畑/水田雑草群落 & 4 & 3 & \multirow{2}{*}{30 草本群落または低木林 } & & \multirow{2}{*}{$\begin{array}{l}\text { 草本もしくは } \\
\text { 木本主体型 } \\
\end{array}$} \\
\hline & 伐採跡地群落 (V) (VII) & 4 & 3 & & & \\
\hline \multirow{2}{*}{ 3. 荒36) } & 低木群落 & 6 & 4 & 13 その他の低木林 & & \\
\hline & クズ群落 & 5 & 4 & 13 その他の低不林 & & \\
\hline & ヤナギ低木/高木群落(VI) & 9 & 5 & 11 ヤナギ低木林/12 ヤナギ高木林 & & \\
\hline & クヌギ-コナラ群集 & 7 & 4 & & & \\
\hline & クリ-コナラ群集 & 7 & 4 & & & \\
\hline & クヌギ群落 $(\mathrm{VI})$ & 9 & 4 & & & \\
\hline & ハンノキ群落(VI) & 9 & 4 & & & \\
\hline & ムクノキ-エノキ群落 & 9 & 5 & & & \\
\hline & イノデ-タブノキ群集 & 9 & 5 & 14 洛枼/枼樹林 & & \\
\hline & アカシデ-イヌシデ群落(VII) & 7 & 4 & & & \\
\hline & ミズキ群落 & 7 & 4 & & & \\
\hline 4. 柳, 榛, 楢, 椚, & オニグルミ群落 $(\mathrm{V})$ & 7 & 5 & & & 大本主体刑 \\
\hline 松, 柫 & 二セアカシア群落 & 3 & 3 & & & 凡本土体型 \\
\hline & シラカシ群集 & 9 & 5 & & & \\
\hline & ケヤキ-シラカシ群落 & 7 & 5 & 16 常緑広葉樹林 & & \\
\hline & シイ・カシ二次林 & 8 & 3 & & & \\
\hline & スギ・ヒノキ・サワラ植林 & 6 & 3 & 19 植林地（スギ・ヒノキ） & & \\
\hline & クロマツ植林 & 6 & 3 & & 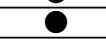 & \\
\hline & アカマツ植林 & 6 & 3 & 20 植林地（その他） & 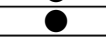 & \\
\hline & その他植林 & 6 & 3 & & $\overline{0}$ & \\
\hline & 残存・植栽樹群地 & 3 & 3 & $\begin{array}{l}13 \text { その他の低木林 } \\
20 \text { 植林地 (その他) }\end{array}$ & & \\
\hline 5 竹 & モウソウチク林 & 3 & 3 & 18 植林地（竹林） & & \\
\hline 5. Т丁 & 竹林 & 3 & 3 & 18 柦林地（仃林） & & \\
\hline 6. 桑桃, 梅, 梨, 㮏 & 果樹園 & 3 & 1 & 21 果樹園 & O & \\
\hline 7. 畑 & 畑雑草群落 & 2 & 1 & 22 畑 & ○ & 開罦刑 \\
\hline 8. 水田, 田 & 水田雑草群落 & 2 & 1 & 23 水田 & 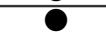 & 闰垢型 \\
\hline 9. 牧 & 牧草地 & 2 & 1 & 24 人工草地 & & \\
\hline & ゴルフ場・芝地 & 4 & 0 & & & \\
\hline- & 残存・植栽樹遅をもつた公園, 墓地等 & 3 & 0 & 25 クラウンドなと & & \\
\hline & 造成地 & 1 & 0 & & & 聞登刑 \\
\hline & 市街地 & 1 & 0 & & & 開発型 \\
\hline 10. 建築物 & 緑の多い住宅地 & 2 & 0 & 26 人工構造物 & O & \\
\hline & 工場地带 & 1 & 0 & & & \\
\hline 11. 砂, 礫, 泥 & 自然裸地 & - & 5 & 27 自然裸地 & & \\
\hline 12. 水域 & 開放水域 & - & - & 28 開放水面 & & 日型 \\
\hline
\end{tabular}

*過去の植生は 10～12. (建築物/砂，磁，泥/水域) を除く 1. 9.の凡例を人為的自然環境に分類した。

* 河川の自然性区分 (0 5) 0 : 人工構造物 1: 人為植生、2:代償植生(外来植生, 退行遷移の結果生じた在来植生) 3:代償植生(二次草地, 植林) 4:自然植生(河川の先駆植生, 河川本来以外の植生) 5 :自然植生(河川本来の植生, 自然裸地)

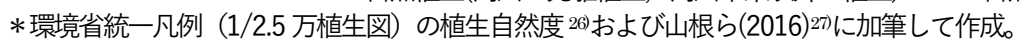

2）堤外地における人為的自然環境のモザイク性評価

これまで行われた人為的自然環境の評価事例として，上述の環 境省による里地里山地域の抽出 ${ }^{25)}$ では, 現存植生図と 3 次メッシ ユ（1 km四方）を用い，メッシュ内に農地，二次草原，二次林を 2 種類以上かつ 45\%以上含むメッシュを「里地里山メッシュ」とし ている。また, Kadoya ら ${ }^{35)}$ は, 標準土地利用メッシュを用いて農 業ランドスケープの生物多様性評価を行い, Satoyama Index と して里地里山指標の地図化を行っている。本研究ではこれらの既 往研究を踏まえ, 堤外地における人為的自然環境の土地利用モザ イク性を評価するため以下の作業を行った。

まず，モザイク性評価の基淮範囲を設定した。環境省やKadoya らの研究と同様に $1 \mathrm{~km}$ 四方の 3 次メッシュを基準範囲にしよう と試みたが， 3 次メッシュは堤内地の植生を含んだ評価となり, 堤外地の環境を適切に評価できない。そこで, 国土地理院の提供 する地形分類図を用いて，1km の河川距離標ごとに堤外地を区切 り， $1 \mathrm{~km}^{2}$ 前後のエリアを作成して基準範囲とした。

次に, 環境省による「里地里山メッシュ」の抽出手法を援用して,
上述の手順により分類された人為的自然環境を 2 種類以上かつ 45\%以上含む「モザイク土地利用エリア」を抽出した。

\section{3. 結果と考察}

\section{（1）人為的自然環境の量}

堤外地に人為的自然環境がどの程度存在するかを明らかにした。 対象 5 河川の堤外地を $100 \mathrm{~m}$ 四方のメッシュに区切ったところ, 全メッシュ数は 30240 メッシュであった。また，そのうち人為的 自然環境として抽出されたメッシュ（以下，人為的自然環境メッ シュ）は 13628 メッシュであり，堤外地のうち $45.1 \%$ 代為的自 然環境であることがわかった (図一2)。さらに, 過去と現在の植生 を「植生タイプ」として類型化したところ，「草本主体型」，「草本 もしくは木本主体型」,「木本主体型」,「開墾型」,「開発型」,「自然 地目型」の 6 タイプに分類できた（表一2）。

具体的な植生タイプの分類は以下の通りである。迅速図におけ る湿地，蘆 (芦，菲，葦)，茅 (萱, 苽), 草等の植生と，現在の草 本群落を「草本主体型」に，迅速図で松，梄，椚等の名称が記され 


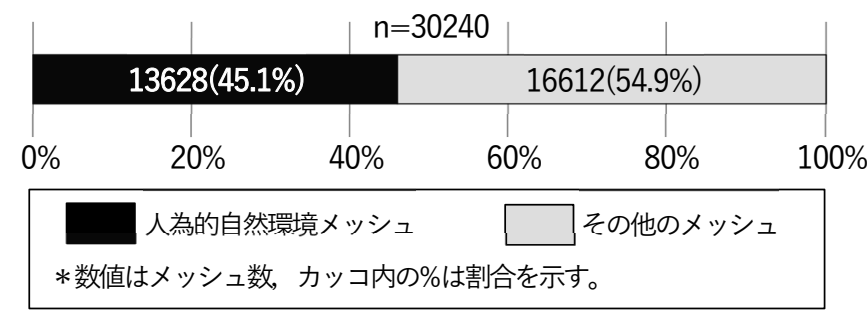

図一2 全メッシュに占める人為的自然環境メッシュの割合

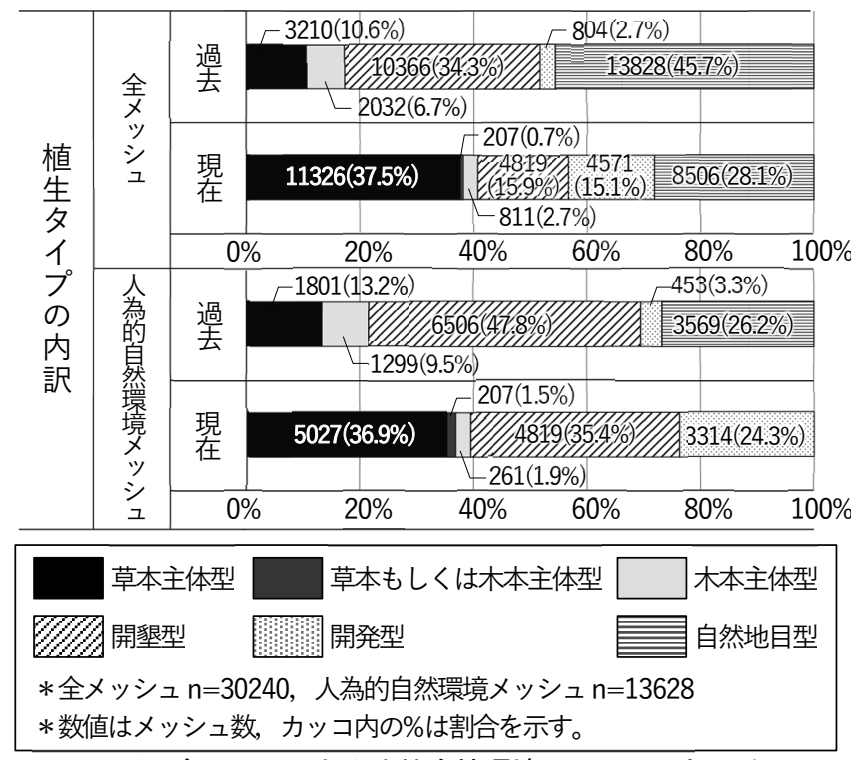

図一3 全メッシュと人為的自然環境メッシュにおける 現在亡過去の植生タイプの内訳

た樹林地および現存植生で木本層に分類される植生を「木本主体 型」とした ${ }^{36)}$ 。また, 迅速図の畑, 田 (水田), 桑, 桃, 牧と, 現 存植生の農地と人工草地を「開墾型」, 集落等の建築物やゴルフ場, 公園等の人工施設を「開発型」, 自然裸地と開放水域からなる砂地, 砂砶地，水域等の地目を「自然地目型」として分類した ${ }^{36)}$ 。

草本主体型植生の分類は, 以下の基淮に依った。過去の植生にお ける湿地は, 周辺植生と同色で彩色される「湿地」及び「沼」とし た。対象地域において「湿地」は全て「草」と同色で記されており， 植生のある水域と考えられるため, 現在の塩沼地植生に分類した。

「草, 蘆, 茅, 苽等」は, 既往研究で草本植生であったことが示さ れている 33)ことや, GIS データの公開元機関において「樹木のな い草本主体の土地利用」と説明されている37)ことから, 河川沿岸 域に生育する単子葉草本に分類した。蘆 (芦, 臀, 葦), 茅 (萱), 苽についての記載方法は『兵法測量軌典』29)には記されていないが, 「草」と同じ方法で記されているため，草本主体型に分類した。

\section{（2）堤外地における人為的自然環境の形成過程}

対象 5 河川の過去と現在の植生タイプの数と割合は図 -3 の通 りであった。全メッシュにおける過去の植生タイプは, 自然地目 型 $(45.7 \%)$, 開墾型 $(34.3 \%)$, 草本主体型 $(10.6 \%)$, 木本主体型 $(6.7 \%)$, 開発型 $(2.7 \%)$ の順に多かった。また, 現在の植生タイ プは, 草本主体型 (37.5\%), 自然地目型 (28.1\%), 開墾型 (15.9\%), 開発型 (15.1\%) の順に多かった。自然地目型と開墾型の割合が減 少し, 草本主体型の割合が大きく増加していることから, 擋乱が 減少していると考えられる。また, その要因としては河川改修に より高水敷となったメッシュがあることや, 流路の固定化, 農耕 地における土地利用の変化が考えられる。

一方で, 人為的自然環境メッシュにおける過去の植生タイプは, 開墾型 $(47.8 \%)$, 自然地目型 $(26.2 \%)$, 草本主体型 $(13.2 \%)$, 木 本主体型 $(9.5 \%)$, 開発型 $(3.3 \%)$ の順に多かった。また, 現在の

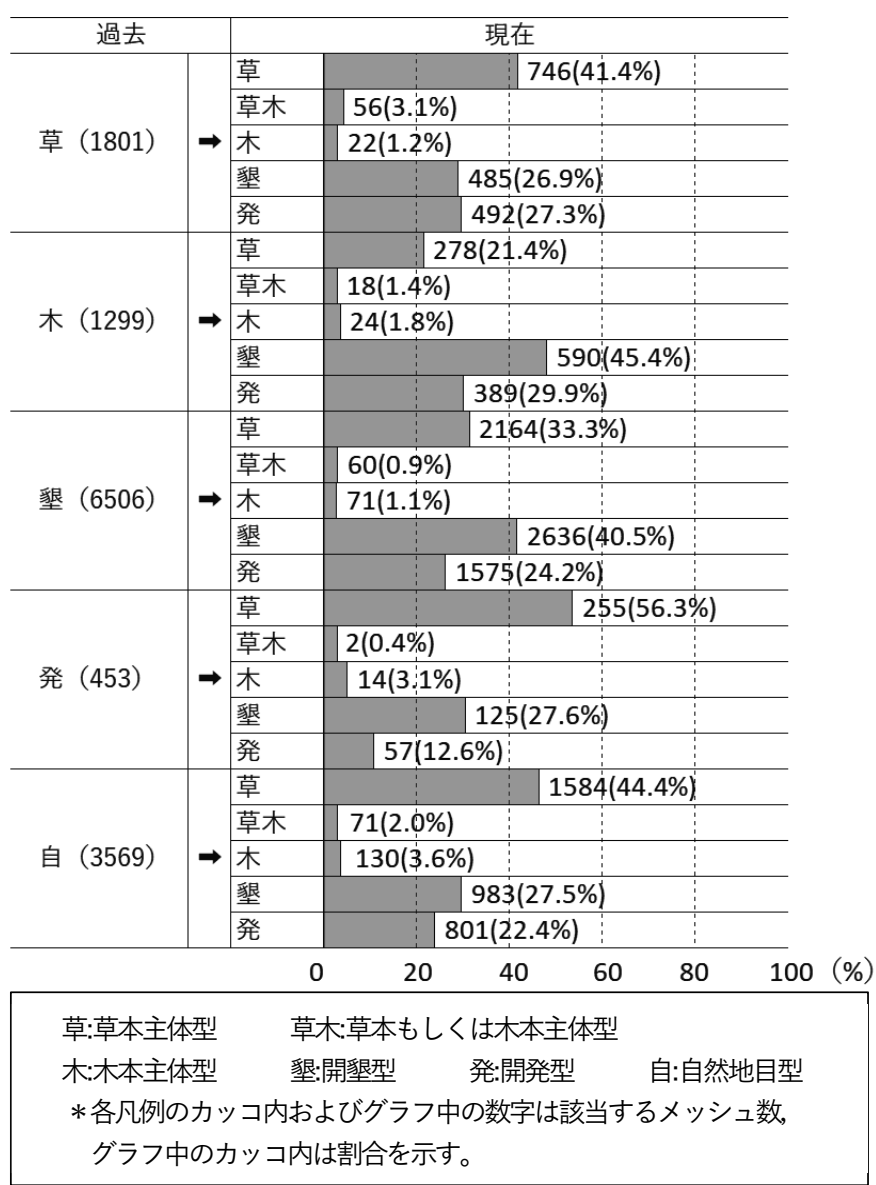

図－4 人為的自然環境メッシュにおける植生タイプの変化

植生タイプは，草本主体型 $(36.9 \%)$, 開墾型 $(35.4 \%)$, 開発型 (24.3\%) 木本主体型 $(1.9 \%)$, 草本もしくは木本主体型 $(1.5 \%)$ であった。このことから, 全メッシュにおける変化と同様に, 人為 的自然環境メッシュでも流水による擋乱の減少や農耕地の土地利 用転換が要因となり，草本主体型が増加していると考えられる。 また，人為的自然環境メッシュで開発型が大幅に増加しているこ とから，ゴルフ場や公園等が整備されたことがわかる。

さらに，人為的自然環境メッシュにおける過去から現在にかけ ての植生タイプの変化を調査したところ, 過去の全ての植生タイ プで草本主体型，開墾型，開発型に変化したメッシュが 90\%以上 を占めた（図一-4）。その内訳をみると，過去に草本主体型，開発 型, 自然地目型の植生タイプであったメッシュは草本主体型に変 化したメッシュが最多であり，木本主体型と開発型は開墾型に変 化したメッシュが最多であった。このことは，上述した自然地目 型の草本主体型への変化と耕作地の増加により説明できるが，草 本主体型は過去と現在で植生の内容が変化している可能性がある。 草本主体型に区分される植生は, 過去には茅 (萱: 115 メッシュ), 草 $(628$ メッシュ), 蘆 (芦, 臀, 葦 : 226 メッシュ), 苽 $(62$ メ ッシュ), 湿地 (260 メッシュ) 等の湿生植生であった。しかし, 現存植生で人為的自然環境に分類される種は，水際部に生育する ヨシ，才ギや砂碩地に生育寸る河畔植生ではなく，ススキやチガ ヤ等の陸域植生である (表一2)。そのため, 人為的自然環境メッシ 二の草本主体型植生は，その内容が変化していると考えられる。

\section{（3）モザイク土地利用エリアの把握}

5 河川の堤外地を河川距離標に基づき $1 \mathrm{~km}$ ごとにエリア分けし たところ，合計 375 個のエリアを作成できた。また，環境省によ

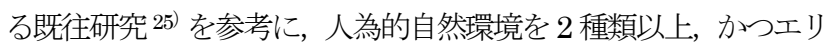
ア面積の 45\%以上を含む「モザイク土地利用エリア」を抽出した ところ，219エリア (58.4\%) が抽出された（図-5)。 


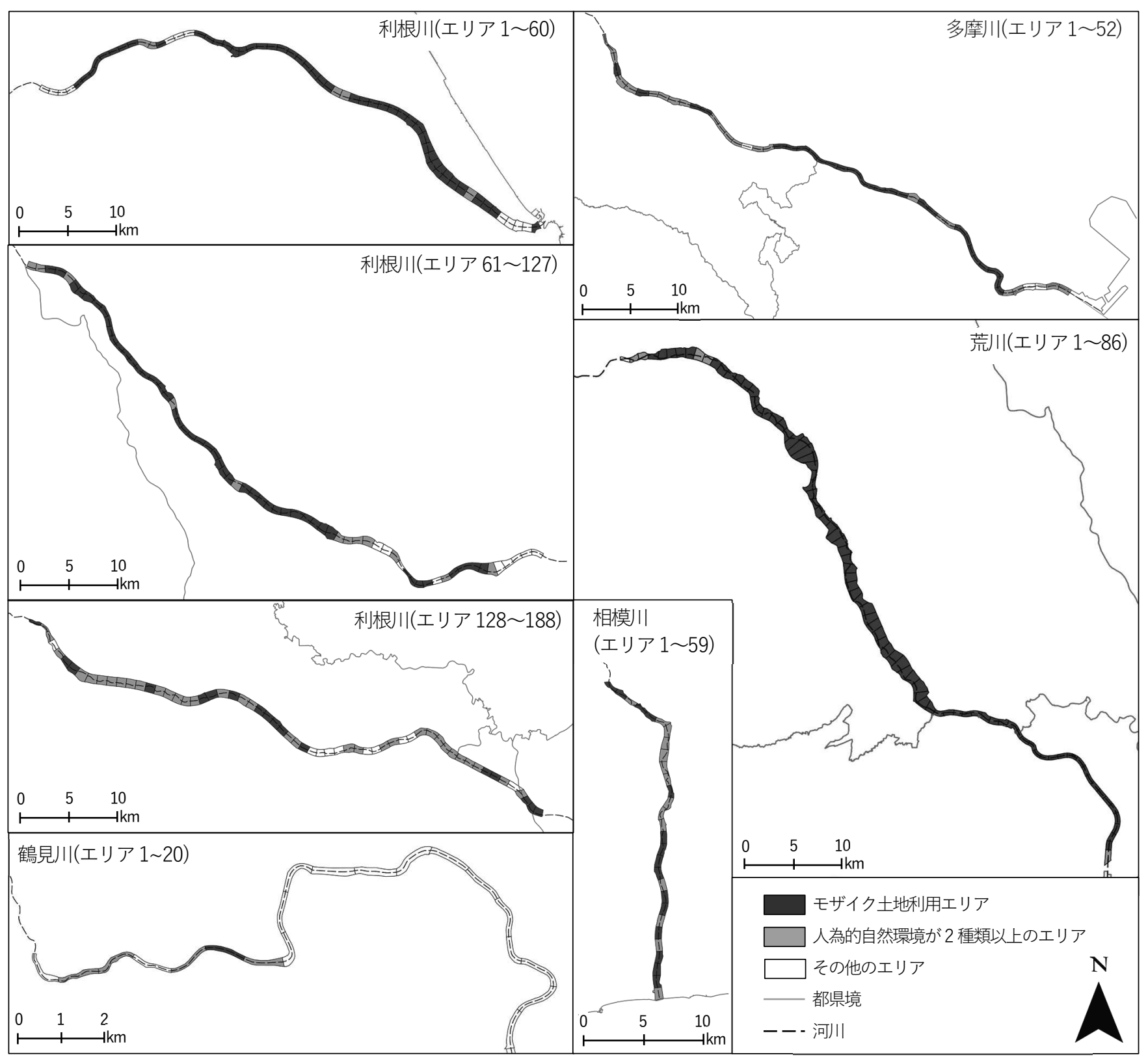

図一5 対象 5 河川の堤外地におけるモザイク土地利用エリアの分布

各河川におけるモザイク土地利用エリアの数と特徵は以下の通 りであった。利根川では全 188 エリアのうち 99 エリア (52.7\%), 荒川では全 86 エリアのうち 78 エリア $(90.7 \%)$, 多摩川では全 52 エリアのうち 26 エリア $(50.0 \%)$, 鶴見川では全 20 エリアのうち 1 エリア $(5.0 \%)$, 相模川では全 29 エリアのうち 15 エリア (51.7\%) がそれぞれモザイク土地利用として抽出された。また，モザイク 土地利用エリアには抽出されなかったものの, エリア内に人為的 自然環境を 2 種類以上含むエリアはモザイク土地利用エリアと連 続性があるものが多く, 堤外地の人為的自然環境はある程度まと まって存在していることがわかった。なお，鶴見川のモザイク土 地利用エリアが少ない理由としては，鶴見川が河川改修により掘 込構造の都市河川となっており, 現在では堤外地の空間利用がな されていないことや, 流路が固定されているために流水による擋 乱の影響度に差異が少ないためであると考えられる。また, 本研 究では河川を $1 \mathrm{~km}$ 延長ごとにエリア分割をしているため, 地点ご とに川幅が異なり生成される各エリアの面積もそれぞれ異なる。 鶴見川は，上記の河川構造による影響のほか，川幅が狭くエリア の面積が狭いため複数の植生種が出現しなかった可能性もある。

\section{4. 総合考察}

以上の分析の結果，人為的自然環境を基盤に成り立つ堤外地の 社会生態学的生産ランドスケープについて以下の示唆が得られた。

（1）堤外地における社会生態学的生産ランドスケープの特性

里地里山地域では, 集落, 耕作地, 焼畑, 採草地, 陰伐地, 茅場, 薪炭林，植林地などがモザイク状に立地することが明らかにされ てきた ${ }^{38)}$ ここれまで河川を対象にした研究は行われてこなかった が, 本研究の調査の結果, 5 河川の堤外地において $45.1 \%$ の人為的 自然環境メッシュがあり, そのうち草本主体型, 開墾型, 開発型の 3 種が 96\%を占めていることがわかった。このことから，堤外地 にはモザイク状土地利用からなる里地里山地域と同質の社会生態 学的生産ランドスケープが形成されているといえる。また，堤外 地は出水による撹乱が発生する環境下にあり，このような河川特 有の自然撹乱がもたらす微細な立地環境の差異が複数種の土地利 用を生成する要因になっていると考えられる。

一方で，鶴見川においてモザイク土地利用エリアが少なかった ように，面的利用が可能な築堤構造の河川と異なり，都市河川な どの堀込構造の河川では，空間利用がなされず人為的自然環境は 
出現しにくいと考えられる。

\section{（2）社会生態学的生産ランドスケープとしての堤外地の変化}

図-3 で示した堤外地の過去の植生タイプから，堤外地には自 然地目の上に農地を主体とする生産空間が成立していたことが示 唆される。従来の里地里山地域では, 産業構造の変化に伴い准民 の地域資源利用・土地利用の形態が変化し, ランドスケープも変 化してきたとされている 38, 39)。堤外地でも草地や樹林地が自然資 源の採集地として利用されてきたことが明らかにされており 10,14 40), 図一 3 において, 現在までに草本主体型のメッシュが大きく増 加していることから, 堤外地でも人の管理停止がランドスケープ の変化要因のひとつになっていると考えられる。

また, 河川環境の変化要因として, ダムや堰といった河川構造物 の建設による洪水撹乱や砂礫供給の減少が指摘されている 40,41)。 前述した河川改修による陸域の増加や撹乱の減少とあわせ，堤外 地の植生内容が変化する要因のひとつになっていると考えられる。

さらに, 堤外地には一定数の私有地が今日も存在している。全国

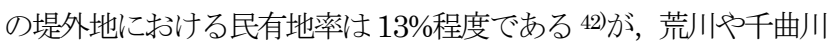
など，1 本の河川単位でみると私有地が $50 \%$ 以上を占める河川も 存在する $\left.{ }^{43}, 44\right)$ 。農地や牧草地, かつての入会地などの人為的自然 環境は私有地に成立している場合が多いため 42 , 河川改修やそれ に伴う私有地の移転，ゴルフ場や公園等への土地利用の転換とい った河川空間の改変により, 堤外地の社会生態学的生産ランドス ケープが今後大きく変化する可能性がある。

\section{（3）河川空間の定量評価における研究方法上の課題と可能性}

本研究では, 堤外地における人為的自然環境の評価を試みたが, 堤外地は流水による自然撹乱が発生する環境であり, 堤外地の被 擋乱環境が人為的要因と自然的要因のどちらに起因するものかを 厳密に判断することが難しい。より厳密な評価を行うためには, 人々の土地への具体的な介入方法や冠水頻度等の経年データも踏 まえたうえで，地目分類を行う等の分析が必要である。

また, 本研究ではこれまで面的空間を対象に行われてきたメッ シュによる土地利用の評価を河川という線的空間に援用して行っ たが, 分析過程において, 堤内の要素を含まないようにするため に半端なメッシュが生成される点や, 最大面積の異なるエリアが 生じる点に方法論上の課題がみられた。

一方で, 具体的な面積ではなく面積の割合を用いたり, 水域をあ らかじめ除いたうえで数值を扱うといった操作により, 河川空間 の陸域に焦点を当てた定量評価を行うことができた。また，河川 の微地形や冠水頻度, 土地所有状況等の情報をさらに重ね合わせ ることで, より詳細な河川空間の実態把握ができると考えられる。

\section{5. おわりに}

従来研究が行われてきた堤内の里地里山地域では, 人と自然の 相互作用により形成されてきた社会生態学的生産ランドスケープ の維持・保全に向けた取組みが進展しているが，河川においては いまだその手法や制度は確立されていない。河川と地域社会の関 係が課題となる今日, 堤外地の社会生態学的生産ランドスケープ を河川の空間的特徵のひとつととらえ, それも含めて河川管理の あり方を考えていく必要がある。

また, 堤外地は堤内地を水害から守るために既存の生活・生産空 間の上に造成された治水施設でもある。堤外地の土地利用の変化 により洪水流の流下阻害となる危険性もあることから, 河川環境 と治水安全性の双方を維持できる河川管理手法を確立することが 不可欠である。人為的自然環境と治水との関連については本研究 では言及できなかったため, 今後の課題としたい。

\section{補注及び引用文献}

1) The International Partnership for the Satoyama Initiative (2010): PARIS D
ECLARATION ON THE "SATOYAMA INITIATIVE", Annex,1

2) プレック研究所 (2009) : 重要里地里山選定等委託業務報告書 上巻: 環境省, pp491 3) プレック研究所(2009) : 重要里地里山選定等委託業務報告書 下巻 : 環境省, pp362 4) 農林水産省(2016) : 世界農業遺産パンフレット, $12 \mathrm{pp}<$ https://www.maff.go.jp/j/nousi n/kantai/attach/pdf/giahs_1-87.pdf > 2020 年 8 月 17 日更新, 2020 年 9 月 3 日閲覧 5) Gulay Cetinkaya Ciftcioglu(2018) : Revealing major terrestrial- and marine species-based provisioning ecosystem services provided by the socio-ecological production landscapes and seascapes of Lefke Region in North Cyprus : Envi ronment, Development and Sustainability volume 20 , 197-221

6) 神山千穂・橋本禅・香坂玲・齊藤修(2016) : 社会生態学的生産ランドスケープにお ける生態系サービス間のシナジーとトレードオフ解析: 石川県下の基礎自治体を事 例として: 土木学会論文集 G(環境)72(6), 289-297

7) Hongyan Gu - Suneetha M. Subramanian(2014) : Drivers of Change in Socio-Eoological ProductionLandscapes:Implicationsfor BetterManagement : EoologyandSociety 19 (1), ページ潘号なし

8）鳥越告之・嘉田由紀子・陣内秀信・沖大幹(2006）：里川の可能性一利水・治水・守水 を共有する : 新曜社, $280 \mathrm{pp}$

9）里川という用語の提昌者である鳥越は，わが国で概念化されている「かわ」はカワ, 川, 河の 3 種類があり，大河川に当てはまる河はあまりにも大きいために人間の日 常の生活領域に入りにく<, 里川の範疇こ入りにくいと述べている 45 )。しかし, 本

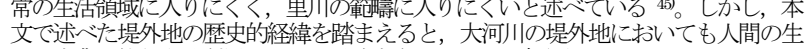
活・生業に伴う土地利用システムが確立されてきたと考えられる。

10)大石学(1996): 享保改革の地域政策 : 吉川公文書館, $322 \mathrm{pp}$

11)大石学(1980) : 享保改革期における流作場開発政策と村落-下利根川流域野木㥓村を 中心に: 徳川林政史研究所研究紀要 (昭和 54 年度), 476-518

12)松尾公就(1981) : 享保改革末期の流作場新田検地につい: 歴史手帳 9(1)，23-32 13)磯谷有紀・橋詰直道(2011): 河川改修に伴う荒川中流域における堤外地集落の移転 䭻澤地理 $47,57-81$

14) 矢澤優理子・古谷勝則(2018) : 埼玉県旧大麻生村の荒川における入会地の土地利用か らみる堤外地の社会的役割の変化, ランドスケープ研究 82(5), 557-562

15)吉田和義(1987) : 千曲川沿岸における地割慣行地の地理学的研究一長野県小布施町山 王島集落の事例一 : 新地理 35(1)，1-13

16)例えば生態学の分野では, Forman R.T.T. Godron M. (1986) : Landscape Ecolo gy : John Wiley and Sons Ltd., 146-155 が著名である。また, 歴史学においても 橋本道範(2009) : 日本中世における水辺の環境と生業一河川と湖沼の漁撈から一: 史 林 92(1), 4-35などがある。

17)Tansley A.G.(1923) : Practical Plant Ecology, George Allen \& Unwill, 42 18)環境省(2016) : 重要里地里山 500 リーフレット, <https://www.env.go.jp/nature/satoya

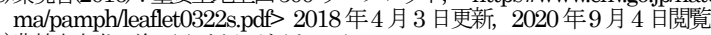

19)農林水産省 : 美の里づくりガイドライン, 46, <https://www.maff.go.jp//nousin/soutyo/bi nosato_gaidorain/pdf/046p055s3s2.pdf 32019 年4月 13 日更新, 2020 年9月 4 日閲覧 20)大澤雅彦 (2005) : 植物群落モニタリングの寸寸め 自然保護に活か寸 植物群落レッ ドデータブック : 文一総合出版, 29-30

21)国立研究開発法人 農業・食品産業技術総合研究機構力酒信寸る同地図をArcGIS 上 で表示させて用いた。

22)藤原道郎(2005): 景観形成プロセス解明の起点としての明治期の景観構造特集にあた つて: 景観生態学 $9(2), 1-2$

23)荒川放水路は用地買收により新設された河川であり堤外地に民有地が存在しないが, 第二次世界大戦による食糧難こ伴い、食糧確保のための耕作が行われた。

24)使用した地形図と空中写真は以下の通り【2 万 5 千分の 1 地形四】「赫」「草加「東 京西部」,「東京南部》(以上1945 年部分修正),「東京首部」(1947資料修正) [空中写真： 整理番号-コース番号写真番号】 USA-M380-30, USA-M504-64, USA-M515A-97, 整埋番号-コース番号一写真番号】 USA-M380-30, USA-M504-64, USA-M515A-97,
USA-M449-193, USA-M449-101(以上1947 年撮影), USA-M860-210, USA-M737 -131, USA-M860-163(以上 1948 年撮影),USA-R3163-43(1949 年撮影

25)環境省(2009) : 里地里山保全・活用検討会議 平成 20 年度第3 回検討会議資料, $<\mathrm{ht}$ tps://www.mlit.go.jp/river/shinngikai blog/shaseishin/kasenbunkakai/bunkakai/1 $2 / \mathrm{pdf} / \mathrm{siryo} 2 \mathrm{pdf}>, 2018$ 年 4 月 3 日更新, 2020 年 5 月 15 日閲覧

26)環境省(2016) : 環境省自然環境局生物多様性センター資料 $1 / 2.5$ 万植生図の新たな植生自 然度につ、 、, <https://www.mlit.go.jp/river/shinngikai_blog/shaseishin/kasenbunkaka i/bunkakai/12/pdf/siryo2.pdfs, 2016 年4月 1 日更新, 2020年5月 17 日閲覧

27)山根明・服部誠一郎・内田泰三(2016) : 九州の河川における植生自然度区分の検討 第 47 回日本緑化工学会大会研究 交流発表会要旨集, 20

28)山根明・服部晠一郎・内田泰三(2016) : 河川環境の定量評価における河川植生の類型 区分に関寸る一考察 : 日本緑化工学会誌 44(1), 151-154

29)陸軍文庫(1881) : 兵要測量軌典 : 陸軍文庫, $411 \mathrm{pp}$

30)陸軍参謀本部(1986) : 明治前期民情調査報告 偵察録 : 柏書房 (マイクロフイルム)

31)小椋純一-(2005) : 人間活動と植生景観 : 景観生態学 $9(2), 3-11$

$32)$ 小椋純一(2010) : 日本の草地の歴史を探る : 日本草地学会誌 56(3), 216-219

33)小椋純一(1993)：明治中期における房総丘陵の植生景観 : 造園杂隹誌 56(5), 25-30

34)岡田昭八・前田諭・松間充(2003) : 河川水辺の国勢調査における植生図凡例の統一に いて: リバーフロント研究所報告 $14,101-108$

35)Kadoya T • Washitani I (2011) : The Satoyama Index: a biodiversity indicator for agricultural landscapes : Agriculture, Ecosystems and Environment 140, 20-26

36)小椋の既往研究 33)では，荒地は砂地や砂礫地を伴う草本植生を示寸ものであると解 釈されている。しかし，『兵法測量軌典』において低木の木本植生を示す「灌木地 や「曂野」と同様の彩色方法で製図するよう指定されていることや, 草本層は「草」 や曠野」と同様の彩色方法で製洞するよう指定されていることや, 草
等の凡例により記載されることから, 「木本主体型」として分類した。

37)農研機構農業環境変動研究センター: 歴史的農業環境閲覧システム, < https://habs dc.affrc.go.jp/habs_faq.html> 2018 年 9 月 12 日更新, 2020 年 8 月 20 日閲覧

38)深町加津枝・大住克博(2001) : 里山林の土地利用およひ管理手法とランドスケープ構 造 : 国際景観生態学日本支部会報 6(1)，25-29

39)堀内美緒・深町加津枝・奥敬一・森本幸裕(2006) : 明治後期の日記にみる滋賀県西部の里 山ランドスケープもおけるリ林資源利用のパターン:ランドスケーフ研究 69(5), $705-710$

40)大石哲也・天野邦彦(2009)：人的利用の変化が河川樹林化に及ぼす影響: 土木技術資 料 $51(1), 42-47$

41)李参熙・山本晃一島谷幸宏・萱場祐一 (1996) : 多摩川扇状地河道部の河道内植生 分布の変化とその変化要因との関連性 : 環境システム研究 $24,26-33$

42)国土交通省(2004) : 社会資本審議会河川分科会第 12 回資料 $2, \mathrm{pp} 2-1,<\mathrm{https}: / / \mathrm{www}$. mlit.go.jp/river/shinngikai_blog/shaseishin/kasenbunkakai/bunkakai/12/pdf/siryo 2.pdf $>, 2020$ 年 10 月 4 日更新, 2020 年 7 月 27 日閲覧

43)国十交通省(2020) : 荒川上流可川事務所ホームページ荒川の土地利用, < https://www.kt mlit.go.jplarajo/arajo00027.html >, 2020年5月 12 日更新, 2020 年 7 月 12 日閲覧

mlit.go.jp/arajolarajo00027.html >,2020 年5月 12 日更新, 2020 年 7 月 12 日閲覧
44)国土交通省干曲川河川事務所(2018) : 千曲川だより,<http://www.hrr.mlit.go.jp/chik uma/news/kawa-dayori/300807shuzai/index.html>, 2012 年 12 月 18 日更新, 20 20 年 7 月 12 日閲覧

45)鳥越的之(2011) : 里川の意味と価值 : 環境技術 40(8)，23

(2020. 9. 26受付, 2021. 3. 30受理) 